\title{
Investigation of multidrug-resistant ST2 Acinetobacter baumannii isolated from Saint George hospital in Lebanon
}

\author{
Tania Nawfal Dagher ${ }^{1,2}$, Charbel Al-Bayssari ${ }^{3}$, Selma Chabou', Nadine Antar ${ }^{2}$, Seydina M. Diene ${ }^{1}$, Eid Azar ${ }^{2}$ and \\ Jean-Marc Rolain ${ }^{1 *}$ (D)
}

\begin{abstract}
Background: Acinetobacter baumannii is an opportunistic pathogen causing various nosocomial infections. The spread of multidrug-resistant $A$. baumannii is a major public health problem. The aim of this study was to investigate the molecular epidemiology and the genetic support of multidrug-resistant A. baumannii isolates collected from Saint-Georges Hospital in Lebanon.

Methods: Between January and August 2016, 31 A. baumannii isolates were collected from sputum samples of patients infected with ventilator-associated pneumonia (VAP) and treated with colistin-carbapenem combination therapy. Antibiotic susceptibility testing was performed using the disk diffusion method. Carbapenemases, extended spectrum $\beta$-lactamases encoding genes and $m c r-1 / 2$ genes were investigated by RT-PCR and standard PCR. The epidemiological relatedness of the strains was studied using MLST analysis.

Results: Most of the isolates exhibited multidrug-resistant phenotypes. All the isolates were carbapenem-resistant and among them, 30 carried the class $D$ carbapenemase $b / a_{\text {oxa-23 }}$ gene while one isolate carried bla $a_{\text {oxa-72 }}$ gene. MLST results revealed three sequence types, namely ST2, ST699, and ST627. Isolates having ST2 were the most prevalent clone (29/31, 93.5\%).

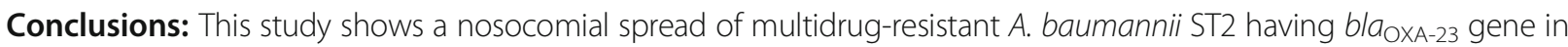
Saint-George in Lebanon. Monitoring and control measures need to be adopted to avoid the spread of A. baumannii to patients.
\end{abstract}

Keywords: Acinetobacter baumannii, OXA-23, ST2 clone

\section{Background}

Acinetobacter baumannii is a glucose non-fermentative, gram-negative, opportunistic pathogen and is one of the leading causes of nosocomial and community infections $[1,2]$. These features make A. baumannii capable of causing a wide variety of clinical complications such as pneumonia, particularly ventilator-associated pneumonia (VAP), bloodstream and urinary tract infections, meningitis, surgical site and wound infections especially in intensive care units $[2,3]$. Carbapenems are the first

\footnotetext{
* Correspondence: jean-marc.rolain@univ-amu.fr

'Aix Marseille Univ, IRD, APHM, MEPHI, IHU-Méditerranée Infection, Faculté de Médecine et de Pharmacie, 19-21 boulevard Jean Moulin, 13385 Marseille, Cedex 05, France

Full list of author information is available at the end of the article
}

choice in the treatment of severe $A$. baumannii infections [4]. Carbapenem resistant $A$. baumannii nosocomial outbreaks have become a major concern worldwide since they lead to limited treatment options [5]. Several mechanisms contribute to carbapenem resistance in $A$. baumannii such as the expression of $\beta$-lactamases, alteration of cell membrane permeability, increased expression of efflux pumps, DNA gyrases, and topoisomerases [1]. In addition, the presence of three different types of $\beta$-lactamases in $A$. baumannii leads to $\beta$-lactame resistance such as: (1) $b l a_{\mathrm{GES}-14,} b l a_{\mathrm{TEM}}, b l a_{\mathrm{SHV}}, b l a_{\mathrm{CTX}-\mathrm{M}}$ and bla $a_{\mathrm{KPC}}$ belonging to Ambler class A $\beta$-lactamases; (2) $b l a_{\mathrm{IMP}-\mathrm{like}}, b l a_{\mathrm{VIM}-\mathrm{like}}, b l a_{\mathrm{SIM}-1}$, and $b l a_{\mathrm{NDM}-1}$ belonging to metallo- $\beta$-lactamases and (3) bla $a_{\mathrm{OXA}-23-\text { like, }} b l a_{\mathrm{OXA}-24-\text { like, }}$ $b l a_{\text {OXA-58-like, }} b l a_{\text {OXA-143 }}, b l a_{\text {OXA-235-like, }}$ and the intrinsic 
$b l a_{\text {OXA-51-like, which are found by nature on the chromo- }}$ some of $A$. baumannii and belonging to oxacillinases [6-8]. Oxacilinases usually do not hydrolyse carbapenems, although some of them produce resistance to carbapenem and are known as "Carbapenem hydrolyzing class D beta-lactamases" or CHDLs. The most common of these enzymes were identified in Acinetobacter spp., notably in A. baumannii, and are responsible for carbapenem resistance [9].

The global dissemination of A. baumannii have been described in several countries in the world such as those of Europe, America, Asia, the Middle East, Australia, and South Africa [10]. A study done by Flamm et al demonstrated that the Mediterranean regions and Europe have the highest frequency of MDR A. baumannii isolates [11]. For example, in South and Southeast Asia, the carbapenem-resistant A. baumannii is a major challenge in public health, where these strains are predominant in nosocomial infections [12]. Regarding Europe, a lower rate of carbapenem resistance was shown in France, Germany and Sweden (10-20, 8 and $4 \%$, respectively) whereas the rates increase up to $50-80 \%$ in Turkey, $85 \%$ in Greece, $60 \%$ in Italy and $45 \%$ in Spain [13]. It has been noticed that in many cases, one or two epidemic strains were perceived in a certain epidemiological setting. This is due to the transfer of colonized patients who transmit these strains between hospitals [14]. To date, in Lebanon, there has been a higher level of carbapenem-resistant $A$. baumannii (CRAB) strains [15]. While the bla $a_{\mathrm{OXA}-24}[16]$ and bla $a_{\text {OXA-58 }}$ [17] have been identified in our country, the bla $a_{\text {OXA-23-like }}$ remains the most common among the CRAB isolates. Furthermore, the international clone ST2 was found to be broadly spread among this country [18]. At the same institution where this present study was done, the outbreak of $A$. baumannii began in 2010 as an epidemic with a high level of resistance due to the high usage of carbapanem [19]. Several studies showed the dissemination of CRAB isolates harboring mainly the $b l a_{\text {OXA-23-like }}$ and belonging to the international clone ST2 $[20,21]$ at Saint-George Hospital. The aim of the current study was to investigate the molecular epidemiology and the genetic support of multidrug-resistant (MDR) A. baumannii isolates collected from patients treated with colistin-carbapenem combination therapy in Saint-George Hospital, Beirut, to investigate if there is a change in the pattern of isolates recovered from patients at the same institution.

\section{Results}

Antimicrobial susceptibility testing of isolated strains

A total of 31 strains isolated from Saint-George Hospital in Beirut were identified by MALDI-TOF as A. baumannii. These isolates were collected from the sputum of the respiratory tract (Table 1). Antibiotic susceptibility testing results revealed high levels of resistance rates of all isolates to ticarcillin, ticarcillin clavulanic acid, piperacillin tazobactam, ceftazidime, cefepime, cefotaxime, imipenem, meropenem, ciprofloxacin, and levofloxacin. In addition, $3.2 \%$ of the isolates were resistant to gentamicin, tobramycin, and amikacin. E-tests showed high-level of resistance to imipenem, with MIC greater than $32 \mu \mathrm{g} / \mathrm{ml}$ for all the isolates. None of the isolates was resistant to colistin ( $\mathrm{MIC}<2 \mu \mathrm{g} / \mathrm{ml}$ ).

\section{Detection of beta lactamase genes}

Results of PCR for carbapenemase-encoding genes showed that $30 / 31$ of the isolates harbored the acquired OXA carbapenemase $b l a_{\text {OXA-23-like }}$ and one isolate expressed the $b l a_{\mathrm{OXA}-24-\text { like }}$ gene.

In addition the $\beta$-lactamases gene $b l a_{\text {TEM }}$ was detected in all isolates. Using ARG-ANNOT, the analysis of the sequenced genes revealed that the $b l a_{\text {OXA-23-like }}$ encoded for the OXA-23 whereas the bla $a_{\text {OXA-24-like }}$ encoded for the OXA-72 variant. All the sequences of the bla $a_{\text {TEM }}$ gene were identified as $b l a_{\mathrm{TEM}-1}$. None of the isolates harbored $b l a_{\mathrm{NDM}-1}, \quad b l a_{\mathrm{OXA}-58}, b l a_{\mathrm{VIM}}$ gene, bla $a_{\mathrm{SHV}}$, $b l a_{\text {СTX-M }}$ and $m c r-1,2,3,4$ and 5 genes.

\section{MLST analysis}

MLST analysis showed that $93.5 \%$ (29/31) of the A. baumannii isolates belonged to ST2 sequence type, whereas two isolates were assigned to ST699 and ST627, respectively. The most common clone (ST2), harboring the bla $a_{\mathrm{OXA}-23}$ and $b l a_{\mathrm{TEM}-1}$ genes, was found to be circulating in the hospital. The isolate belonging to ST627 was associated with the production of the bla $a_{\mathrm{OXA}-72}$ and blaTEM-1 genes (Table 1).

\section{Discussion}

Acinetobacter baumannii has been identified as one of the most successful pathogens responsible for nosocomial infections especially for patients admitted to intensive care units (ICUs) [22]. A. baumannii is able to acquire resistance to broad types of antibiotics including carbapenems. Carbapenem-resistant A. baumannii has been reported worldwide and has become a significant health problem due to the limited options for antibiotic treatment [23, 24].

Between 1999 to 2009, carbapenem-resistant A. baumannii harboring the bla OXA-58 gene were predominant in the hospital flora of many Mediterranean countries such as Lebanon, Italy, Greece, and Turkey [25]. After 2009, a huge shift from OXA-58 A. baumannii to OXA-23 producing belonging to the international clonal I and II lineages has been observed globally [25].

An outbreak of MDR A. baumannii has been observed in Saint George Hospital in Beirut, Lebanon between November 2004 and October 2005 [17]. 
Table 1 Phenotypic and genotypic features of 31 Acinetobacter baumannii isolated from Saint Georges hospital in Lebanon

\begin{tabular}{|c|c|c|c|c|c|c|c|c|}
\hline Isolate & $M / F$ & Collection date & Types of sputum & IPM & IMP MIC ( $\mu \mathrm{g} / \mathrm{ml})$ & Carbapenemases & ESBL & MLST \\
\hline 1 & $M$ & $10-06-16$ & Upper Respiratory Tract & $\mathrm{R}$ & $>32$ & OXA-23 & TEM-1 & ST2 \\
\hline 2 & M & 06-07-16 & Upper Respiratory Tract & $\mathrm{R}$ & $>32$ & OXA-23 & TEM-1 & ST2 \\
\hline 3 & M & 08-06-16 & Upper Respiratory Tract & $\mathrm{R}$ & $>32$ & OXA-23 & TEM-1 & ST2 \\
\hline 4 & $\mathrm{~F}$ & 23-07-16 & Upper Respiratory Tract & $\mathrm{R}$ & $>32$ & OXA-23 & TEM-1 & ST2 \\
\hline 5 & M & $10-06-16$ & Upper Respiratory Tract & $\mathrm{R}$ & $>32$ & OXA-23 & TEM-1 & ST2 \\
\hline 6 & M & $08-08-16$ & Upper Respiratory Tract & $\mathrm{R}$ & $>32$ & OXA-23 & TEM-1 & ST2 \\
\hline 7 & M & $20-06-16$ & Upper Respiratory Tract & $\mathrm{R}$ & $>32$ & OXA-23 & TEM-1 & ST2 \\
\hline 8 & $\mathrm{~F}$ & $01-07-16$ & Upper Respiratory Tract & $\mathrm{R}$ & $>32$ & OXA-23 & TEM-1 & ST2 \\
\hline 9 & M & $15-06-16$ & Upper Respiratory Tract & $\mathrm{R}$ & $>32$ & OXA-23 & TEM-1 & ST2 \\
\hline 10 & $\mathrm{~F}$ & $07-07-16$ & Upper Respiratory Tract & $\mathrm{R}$ & $>32$ & OXA-23 & TEM-1 & ST2 \\
\hline 11 & $\mathrm{~F}$ & $06-02-16$ & Upper Respiratory Tract & $\mathrm{R}$ & $>32$ & OXA-23 & TEM-1 & ST2 \\
\hline 12 & $\mathrm{~F}$ & $30-03-16$ & Upper Respiratory Tract & $\mathrm{R}$ & $>32$ & OXA-23 & TEM-1 & ST2 \\
\hline 13 & M & $16-03-16$ & Upper Respiratory Tract & $\mathrm{R}$ & $>32$ & OXA-23 & TEM-1 & ST2 \\
\hline 14 & $\mathrm{~F}$ & $15-02-16$ & Upper Respiratory Tract & $\mathrm{R}$ & $>32$ & OXA-23 & TEM-1 & ST2 \\
\hline 15 & M & $11-03-16$ & Upper Respiratory Tract & $\mathrm{R}$ & $>32$ & OXA-23 & TEM-1 & ST2 \\
\hline 16 & M & $02-05-16$ & Upper Respiratory Tract & $\mathrm{R}$ & $>32$ & OXA-23 & TEM-1 & ST2 \\
\hline 17 & M & $14-01-16$ & Upper Respiratory Tract & $\mathrm{R}$ & $>32$ & OXA-23 & TEM-1 & ST2 \\
\hline 18 & M & $28-01-16$ & Upper Respiratory Tract & $\mathrm{R}$ & $>32$ & OXA-23 & TEM-1 & ST2 \\
\hline 19 & M & $06-02-16$ & Upper Respiratory Tract & $\mathrm{R}$ & $>32$ & OXA-23 & TEM-1 & ST2 \\
\hline 20 & M & 08-02-16 & Upper Respiratory Tract & $\mathrm{R}$ & $>32$ & OXA-23 & TEM-1 & ST2 \\
\hline 21 & M & 24-03-16 & Upper Respiratory Tract & $\mathrm{R}$ & $>32$ & OXA-23 & TEM-1 & ST2 \\
\hline 22 & $\mathrm{~F}$ & $28-01-16$ & Upper Respiratory Tract & $\mathrm{R}$ & $>32$ & OXA-23 & TEM-1 & ST2 \\
\hline 23 & M & $31-01-16$ & Upper Respiratory Tract & $\mathrm{R}$ & $>32$ & OXA-23 & TEM-1 & ST2 \\
\hline 24 & M & 08-03-16 & Upper Respiratory Tract & $\mathrm{R}$ & $>32$ & OXA-23 & TEM-1 & ST2 \\
\hline 25 & M & 08-03-16 & Upper Respiratory Tract & $\mathrm{R}$ & $>32$ & OXA-23 & TEM-1 & ST2 \\
\hline 26 & $\mathrm{~F}$ & $27-01-16$ & Upper Respiratory Tract & $\mathrm{R}$ & $>32$ & OXA-23 & TEM-1 & ST699 \\
\hline 27 & M & $31-01-16$ & Upper Respiratory Tract & $\mathrm{R}$ & $>32$ & OXA-23 & TEM-1 & ST2 \\
\hline 28 & $\mathrm{~F}$ & $30-01-16$ & Upper Respiratory Tract & $\mathrm{R}$ & $>32$ & OXA-23 & TEM-1 & ST2 \\
\hline 29 & M & $16-02-16$ & Upper Respiratory Tract & $\mathrm{R}$ & $>32$ & OXA-23 & TEM-1 & ST2 \\
\hline 30 & M & $12-01-16$ & Lower Respiratory Tract & $\mathrm{R}$ & $>32$ & OXA-23 & TEM-1 & ST2 \\
\hline 31 & M & $12-01-16$ & Lower Respiratory Tract & $\mathrm{R}$ & $>32$ & OXA-72 & TEM-1 & ST627 \\
\hline
\end{tabular}

$M$ male, $F$ female, ESBL extended spectrum ß-lactamases, MLST multilocus sequence typing, ST sequence type

In our study, the $b l a_{\mathrm{OXA}-23}$ gene was found in 30 carbapenem-resistant $A$. baumannii isolates (96.7\%) recovered from Saint George hospital in Beirut. In 2015, a study done in Lebanon showed the predominance of Imipenem-resistant $A$. baumannii bla $a_{\mathrm{OXA}-23}$ and $b_{\mathrm{GES}-11}$ gene -among the majority of $A$. baumannii. This dissemination of OXA-23 carbepenemase in Lebanon is consistent with the worldwide epidemiology of OXA-23 [16]. Also in 2016, Al Atrouni et al. showed the high dissemination of carbapenem-resistant $A$. baumannii harboring the $b l a_{\mathrm{OXA}-23}$ gene and belonging to the international clone II lineage [26] (Table 2).

All the isolates in our study were resistant to imipenem. In Lebanon in 2012, it has been shown that $88 \%$ of $A$. baumannii were imipenem-resistant. This number is closely related to the rates of 70\% in Egypt, $24-72 \%$ in Turkey, 25-75\% in Spain, and approximating 100\% in Italy [16].

In addition to the $b l a_{\mathrm{OXA}-23}$ gene, we identified the presence of the $b l a_{\text {OXA-24-like }}$ gene in one isolate. A study in Lebanon showed that there was a replacement of the predominant OXA-58 producing $A$. baumannii by OXA-23 producers and belonged to the International Clone II, using isolates recovered from patients from the same institution as those used in the present study, as well as there was the presence of $b l a_{\text {OXA-24-like }}$ gene in two isolates that harbored also the $b l a_{\text {OXA-23-like }}$ gene [20]. Our study revealed that the $b l a_{\text {OXA-24-like }}$ encoded for the OXA-72 
Table 2 Study of carbapenemase Acinetobacter baumannii in Lebanon

\begin{tabular}{|c|c|c|c|c|}
\hline Origine & Carbapenemase genes & $\begin{array}{l}\text { Other resistant } \\
\text { genes }\end{array}$ & ST & Ref \\
\hline Clinical isolates & OXA-23, OXA-24, OXA-58, NDM-1 & & $\begin{array}{l}\text { ST2, ST25, ST46, ST85, ST193, ST424, ST570, ST85, ST600, ST622, ST636, ST690, } \\
\text { ST702, ST715, ST706, ST707, ST1, ST708, ST713, ST807, ST808, ST809, ST810, } \\
\text { ST811 and ST812 }\end{array}$ & [26] \\
\hline Clinical isolates & OXA-23, OXA-24 & & ST2, ST4, ST10 and ST14 & [20] \\
\hline Clinical isolates & OXA-23, OXA-24, OXA-58 & & & [30] \\
\hline Clinical isolates & $\begin{array}{l}\text { OXA-23, OXA-51, OXA66, } \\
\text { OXA69, NDM-1 }\end{array}$ & & $\begin{array}{l}\text { ST2, ST1, ST460, ST85, ST6, ST25, ST103, ST154, ST3, ST158, ST146, ST459, } \\
\text { ST284, ST150, ST108, ST461, ST462 }\end{array}$ & [31] \\
\hline Clinical isolates & MBL, OXA & & & [46] \\
\hline Clinical isolates & OXA-143 & & ST286 to ST296 and ST464 to ST476 & [47] \\
\hline Clinical isolates & OXA-71 & & & [48] \\
\hline Clinical isolates & OXA-23, OXA-24 & & ST2 & [21] \\
\hline Clinical isolates & OXA-58 & GES-5 & & [49] \\
\hline Clinical isolates & OXA-23, OXA-24 & GES-11 & & [15] \\
\hline Clinical isolates & OXA-23, OXA-24 & GES-11 & & {$[50]$} \\
\hline Livestock & OXA-23, OXA-58 & & ST491, ST492, ST493, ST2 and ST20 & {$[51]$} \\
\hline
\end{tabular}

ST Sequence Type, Ref reference

variant, which was firstly reported in 2004 in an $A$. baumannii isolated from Thailand. After that the Acinetobacter spp. who carried this gene have been reported in different countries [27]. In Lebanon, the bla $a_{\text {OXA-72 }}$ was firstly described in A. calcoaceticus isolated from purchased vegetables in Beirut [28]. It is also found in $A$. pittii isolated from patients admitted to Lebanese hospital in North of Lebanon, in 2015 [29]. Moreover, Rafei et al reported that among 31 carbapenem-resistant strains collected from different hospitals in Beirut and Northern Lebanon, 28 isolates carried the $b l a_{\text {OXA-23 }}$ gene, 1 strain the $b l a_{\text {OXA-24 }}$ gene and 2 strains the $b l a_{\text {OXA-58 }}$ gene [30]. She also reported in 2015 the spread of the international clone II lineage with high incidence of $b l a_{\text {OXA-23 }}$ carbapenemase, in addition to the presence of $b l a_{\mathrm{NDM}-1}, b l a_{\mathrm{OXA}-51}$, $b l a_{\text {OXA-66 }}$ and $b l a_{\text {OXA-69 }}$ in different hospitals in Tripoli, Lebanon [31].

Moreover, we found that the majority of our strains harbored the B-lactamases $b l a_{\mathrm{TEM}-1}$ gene. A study in Egypt in 2017 showed that $b l a_{\mathrm{TEM}}$ is the most frequent gene for ESBL [32]. In Saudi Arabia, Aly et al revealed that some of the isolates harbored the $b l a_{\mathrm{TEM}}$ resistance genes as well as the bla $a_{\mathrm{PER}-1}$ gene [33]. Also in Turkey, a study by Beris showed that bla $a_{\text {TEM }}$ was the most prevalent ESBL type amongst $A$. baumannii strains isolated from different regions [34].

In our study, the analysis of MLST showed that the strains belonged to three different clones, ST2, ST699, and ST627, where the ST2 was the most common clone (29/31). The ST2 and ST699 clones were associated with the production of OXA-23 carbapenemase, and the clone ST627 was associated with OXA-72. The ß-lactamases
(ESBL) bla $a_{\mathrm{TEM}-1}$ gene was found in all STs clones (Table 1). It has been shown that the international complexes $\mathrm{CC} 1, \mathrm{CC} 2$, and $\mathrm{CC} 3$ account for the most $A$. baumannii infections around the world and are frequently related with the production of OXA-23-like, OXA-24-like, or OXA-58-like enzymes [35]. Moreover, a study was done by the SENTRY Antimicrobial Surveillance Program in six countries of the Asia-Pacific region such as China, Hong Kong, India, Korea, Singapore and Thailand showed that there was a high distribution of $A$. baumannii having the bla OxA-23 carbapenemase genes [36]. In addition, in the United States, the OXA-23 has been described as the major mechanism responsible to the resistance of A. baumannii. These outbreaks are mostly associated to the worldwide spread of the international clones I and II [37]. The ST2 clone has also been reported in several Mediterranean countries. From 1999 to 2009, a study in four Mediterranean countries (Greece, Italy, Lebanon and Turkey) showed that A. baumannii outbreaks were caused by the spread of strains belonging in particular to ST2 and, to a lesser extent to ST1, ST25, ST78 and ST20. These clones harbored the $b l a_{\text {OXA-58 }}, b l a_{\text {OXA-23 }}$ and $b l a_{O X A-72}$ genes [18]. In Greece, it has been observed that the ST2 was the most common clone circulating in Greek hospitals. These clones harbored the $b l a_{\text {OXA-23 }}$ gene that was displacing the $b l a_{\text {OXA-58 }}$ gene, which was the only carbapenemase found among carbapenem-resistant A. baumannii isolates until 2009 [38]. Moreover, the clone ST699, which belongs to the international clone $\mathrm{CC} 2$, was found for the first time in Lebanon but was reported in Beijing, China in a study that described the predominance of ST699 in 
65 out of 97 clinical A. baumannii isolates collected from patients having nosocomial bloodstream infection [39]. In addition, the clone ST627, was also found for the first time in Lebanon, and was reported in Thailand in the database of Pasteur institute without a published paper.

\section{Conclusion}

In conclusion, this study describes the detection of bla $a_{\mathrm{OXA}-23}$, and $b l a_{\mathrm{OXA}-72}$ genes in clinical isolates of $A$. baumanii in Lebanon. MLST showed that there was a major circulating clone ST2. In addition, the ST699 and ST627 clones had not been previously detected in Lebanon. The resistant A. baumannii isolates found in Saint George hospital in Lebanon in the present study belonged to international clone II lineage and harbored the $b l a_{\mathrm{OXA}-23}$, which were firstly reported by Dahdouh et al and then again by Soudeiha et al in the same institution. Thus, it is clear that this clone has become endemic in the hospital and that an urgent strategy needs to be adopted to control the spread of such resistant microorganisms among patients as well as appropriate infection control measures and surveillance programs must be implemented. In addition, we believe that it is necessary to set up quality training for health professionals to promote a safe environment for staff, patients and visitors, in order that the risk of healthcare associated infections are kept to a minimum.

\section{Methods}

\section{Bacterial isolates}

Between January and August 2016, 31 A. baumannii were isolated from sputum of the respiratory tract of patients infected with ventilator-associated pneumonia (VAP) and receiving colistin-carbapenem combination therapy in Saint-George Hospital in Beirut. 29/31 samples were collected from the sputum of the upper respiratory tract and 2/31 from the sputum of the lower respiratory tract from hospitalized patients and kept at $-80^{\circ} \mathrm{C}$ before being transported to the laboratory in Marseille. Once arrived, the isolates were cultivated for $24 \mathrm{~h}$ at $37^{\circ} \mathrm{C}$ on Trypticase Sodium Agar medium (TSA). Colonies growing on this medium were identified using matrix-assisted laser desorption/ionization time-of-flight mass spectrometry (MALDI-TOF MS) (Microflex; Bruker Daltonics, Bremen, Germany) as previously described [40].

\section{Antibiotic susceptibility testing}

The antibiotic susceptibility testing was performed using the disk diffusion method on Mueller-Hinton agar as recommended by the European Committee of Antimicrobial Susceptibility Testing (EUCAST) 2017. Fourteen different antibiotics were tested: ticarcillin, ticarcillin clavulanic acid, piperacillin tazobactam, ceftazidime, cefepime, imipenem, meropenem, gentamicin, amikacin, tobramycin, colistin, ciprofloxacin, levofloxacin, and cefotaxime. Interpretations of the results of antibiotic sensitivity testing were made according to EUCAST recommendations. In addition, E-test method (bioMérieux) was performed to determine the minimal inhibitory concentration (MIC) of imipenem as recommended by the 2017 European Committee of Antimicrobial Susceptibility Testing (EUCAST).

Moreover, the minimal inhibitory concentration (MIC) of colistin was determined using the broth microdilution method (Biocentric) according to EUCAST 2017.

\section{DNA extraction}

Bacterial DNA was extracted using the automatic robot EZ1 (Qiagen BioRobot EZ1-, Tokyo, Japan), with the extraction kit (EZ1 DNA, Qiagen, Hilden, Germany), following the manufacturer's instructions. The extracted DNA was eluted in $200 \mathrm{~mL}$ of elution buffer and was stored at $-20^{\circ} \mathrm{C}$.

\section{Screening of samples by real-time PCR and molecular characterization of beta lactamase genes}

Real-time PCR was performed to screen for the presence of carbapenemase-encoding genes using specific primers previously described for $b l a_{\mathrm{NDM}-1}, b l a_{\mathrm{OXA}-23}$, $\mathrm{bla}_{\mathrm{OXA}-24}, b l a_{\mathrm{OXA}-58}, b l a_{\mathrm{VIM}}$ and $b l a_{\mathrm{SHV}}$. All MDR bacteria were also screened for $\beta$-lactamases (bla $a_{\text {CTX-M }}$, $b l a_{\mathrm{TEM}}, b l a_{\mathrm{SHV}}$ genes and for the $m c r-1,2,3,4$ and 5 genes as described previously [41-44]. Negative and positive controls were used in each assay. The positive PCR products for any gene tested were sequenced using BigDye1 terminator chemistry on an automated ABI 3130 sequencer (PE Applied Biosystems, Foster City, $\mathrm{CA}$ ). The sequences of the genes obtained were analyzed using the ARG-ANNOT database [45] (http:// backup.mediterranee-infection.com/article.php?laref $=282 \&$ titre $=$ arg-annot), and compared to other genes using the BlastN and BlastP of the National Center for Biotechnology Information (NCBI) database (https:// blast.ncbi.nlm.nih.gov/BlastAlign.cgi).

\section{Multilocus sequence typing}

Molecular typing of the isolates was done to determine the genetic relationship among the clinical isolates by using the seven housekeeping genes (cpn60, fusA, gltA, pyrG, recA, rplB, and rpoB) as described on Institute Pasteur's MLST Web site (https://pubmlst.org/abaumannii). Each single locus has different allele and the allelic profile or sequence types (ST) of the seven loci were given a specific identification number.

\section{Abbreviations}

AST: Antibiotic susceptibility testing; ESBL: Extended spectrum beta lactamase; MALDI-TOF: Matrix-assisted laser desorption and ionization 
time-of-flight mass spectrometry; MDR-AB: Multidrug-resistant Acinetobacter baumannii; MLST: Multilocus sequence typing; PCR: Polymerase chain reaction; RT-PCR: Real time polymerase chain reaction; ST: Sequence type

\section{Acknowledgments}

The authors thank CookieTrad for English language corrections.

\section{Funding}

This work was supported by the Lebanese Council for Research and the French Government under the «Investissements d'avenir » (Investments for the Future) program managed by the Agence Nationale de la Recherche (ANR, fr: National Agency for Research), (reference: Méditerranée Infection 10-IAHU-03. This work was supported by Région Provence Alpes Côte d'Azur and European funding FEDER PRIMI.

\section{Availability of data and materials}

Not applicable.

\section{Authors' contributions}

TND and SC wrote the manuscript, performed experiments, and analyzed the data. EA and NA provided the strains and helped draft the manuscript. CAB and SMD helped draft the manuscript. JMR conceived the study, participated in its design and coordination, and helped draft the manuscript. All authors read and approved the final manuscript.

\section{Ethics approval and consent to participate}

Not applicable. No formal ethics approval was required.

\section{Consent for publication}

Not applicable.

\section{Competing interests}

The authors declare that they have no competing interests.

\section{Publisher's Note}

Springer Nature remains neutral with regard to jurisdictional claims in published maps and institutional affiliations.

\section{Author details}

'Aix Marseille Univ, IRD, APHM, MEPHI, IHU-Méditerranée Infection, Faculté de Médecine et de Pharmacie, 19-21 boulevard Jean Moulin, 13385 Marseille, Cedex 05, France. ${ }^{2}$ Saint George Hospital University Medical Center, Faculty of Medicine and Medical Sciences, University of Balamand, Beirut, Lebanon. ${ }^{3}$ Faculty of Sciences III, Lebanese University, Tripoli, Lebanon.

\section{Received: 25 July 2018 Accepted: 24 January 2019}

\section{Published online: 02 February 2019}

\section{References}

1. Rolain J-M, Diene SM, Kempf M, Gimenez G, Robert C, Raoult D. Real-time sequencing to decipher the molecular mechanism of resistance of a clinical pan-drug-resistant Acinetobacter baumannii isolate from Marseille, France. Antimicrob Agents Chemother. 2013;57:592-6.

2. Zarrilli R, Crispino M, Bagattini M, Barretta E, Di Popolo A, Triassi M, et al. Molecular epidemiology of sequential outbreaks of Acinetobacter baumannii in an intensive care unit shows the emergence of carbapenem resistance. J Clin Microbiol. 2004:42:946-53.

3. Pogue JM, Mann T, Barber KE, Kaye KS. Carbapenem-resistant Acinetobacter baumannii: epidemiology, surveillance and management. Expert Rev AntiInfect Ther. 2013;11:383-93.

4. Ramoul A, Loucif L, Bakour S, Amiri S, Dekhil M, Rolain J-M. Cooccurrence of bla NDM-1 with bla OXA-23 or bla OXA-58 in clinical multidrug-resistant Acinetobacter baumannii isolates in Algeria. J Glob Antimicrob Resist. 2016;6:136-41.

5. Bakour S, Olaitan AO, Ammari H, Touati A, Saoudi S, Saoudi K, et al. Emergence of colistin- and carbapenem-resistant Acinetobacter baumannii ST2 clinical isolate in Algeria: first case report. Microb Drug Resist. 2015;21:279-85.

6. Biglari S, Hanafiah A, Mohd Puzi S, Ramli R, Rahman M, Lopes BS. Antimicrobial resistance mechanisms and genetic diversity of multidrug- resistant Acinetobacter baumannii isolated from a teaching hospital in Malaysia. Microb Drug Resist. 2017;23:545-55.

7. Mathlouthi N, El Salabi AA, Ben Jomàa-Jemili M, Bakour S, Al-Bayssari C, Zorgani AA, et al. Early detection of metallo- $\beta$-lactamase NDM-1- and OXA23 carbapenemase-producing Acinetobacter baumannii in Libyan hospitals. Int J Antimicrob Agents. 2016;48:46-50.

8. Evans BA, Amyes SGB. OXA $\beta$-Lactamases. Clin Microbiol Rev. 2014;27:241-63.

9. Antunes LCS, Visca P, Towner KJ. Acinetobacter baumannii: evolution of a global pathogen. Pathog Dis. 2014;71:292-301.

10. Huber CA, Sartor AL, Mcodimba F, Shah R, Shivachi P, Sidjabat HE, et al. Outbreaks of multidrug-resistant Acinetobacter baumannii strains in a Kenyan teaching hospital. Integr Med Res. 2014;2:190-3.

11. Flamm RK, Castanheira M, Streit JM, Jones RN. Minocycline activity tested against Acinetobacter baumannii complex, Stenotrophomonas maltophilia and Burkholderia cepacia species complex isolates from a global surveillance program (2013). Diagn Microbiol Infect Dis. 2016;85:352-5.

12. Hsu L-Y, Apisarnthanarak A, Khan E, Suwantarat N, Ghafur A, Tambyah PA Carbapenem-Resistant Acinetobacter baumannii and Enterobacteriaceae in South and Southeast Asia. Clin Microbiol Rev. 2017;30:1-22.

13. Kempf M, Rolain J-M, Azza S, Diene S, Joly-Guillou M-L, Dubourg G, et al. Investigation of Acinetobacter baumannii resistance to carbapenems in Marseille hospitals, south of France: a transition from an epidemic to an endemic situation. APMIS. 2013;121:64-71.

14. Peleg AY, Seifert $H$, Paterson DL. Acinetobacter baumannii: emergence of a successful pathogen. Clin Microbiol Rev. 2008;21:538-82.

15. Hammoudi Halat D, Moubareck CA, Sarkis DK. Heterogeneity of carbapenem resistance mechanisms among gram-negative pathogens in Lebanon: results of the first cross-sectional countrywide study. Microb Drug Resist. 2017;23:733-43.

16. Hammoudi D, Moubareck CA, Hakime N, Houmani M, Barakat A, Najjar Z, et al. Spread of imipenem-resistant Acinetobacter baumannii coexpressing OXA-23 and GES-11 carbapenemases in Lebanon. Int J Infect Dis. 2015;36:56-61.

17. Zarrilli R, Vitale D, Di Popolo A, Bagattini M, Daoud Z, Khan AU, et al. A plasmid-borne blaOXA-58 gene confers imipenem resistance to Acinetobacter baumannii isolates from a Lebanese hospital. Antimicrob Agents Chemother. 2008;52:4115-20.

18. Di Popolo A, Giannouli M, Triassi M, Brisse S, Zarrilli R. Molecular epidemiological investigation of multidrug-resistant Acinetobacter baumannii strains in four Mediterranean countries with a multilocus sequence typing scheme. Clin Microbiol Infect. 2011;17:197-201.

19. Ballouz T, Aridi J, Afif C, Irani J, Lakis C, Nasreddine R, et al. Risk factors, clinical presentation, and outcome of Acinetobacter baumannii bacteremia. Front Cell Infect Microbiol. 2017;7:156.

20. Dahdouh E, Hajjar M, Suarez M, Daoud Z. Acinetobacter baumannii isolated from Lebanese patients: phenotypes and genotypes of resistance, Clonality, and determinants of pathogenicity. Front Cell Infect Microbiol. 2016;6:163.

21. Soudeiha MAH, Dahdouh EA, Azar E, Sarkis DK, Daoud Z. In vitro evaluation of the colistin-carbapenem combination in clinical isolates of $A$. baumannii using the checkerboard, Etest, and time-kill curve techniques. Front Cell Infect Microbiol. 2017:7:209.

22. Blanco N, Harris AD, Rock C, Johnson JK, Pineles L, Bonomo RA, et al. Risk factors and outcomes associated with multidrug-resistant Acinetobacter baumannii upon intensive care unit admission. Antimicrob Agents Chemother. 2017:62:e01631-17.

23. Zarrilli R, Pournaras S, Giannouli M, Tsakris A. Global evolution of multidrug-resistant Acinetobacter baumannii clonal lineages. Int J Antimicrob Agents. 2013;41:11-9.

24. Kempf M, Rolain J-M. Emergence of resistance to carbapenems in Acinetobacter baumannii in Europe: clinical impact and therapeutic options. Int J Antimicrob Agents. 2012;39:105-14.

25. Liakopoulos A, Miriagou V, Katsifas EA, Karagouni AD, Daikos GL, Tzouvelekis LS, et al. Identification of OXA-23-producing Acinetobacter baumannii in Greece, 2010 to 2011. Euro Surveill. 2012;17:20117

26. Al Atrouni A, Hamze M, Jisr T, Lemarié C, Eveillard M, Joly-Guillou M-L, et al. Wide spread of OXA-23-producing carbapenem-resistant Acinetobacter baumannii belonging to clonal complex II in different hospitals in Lebanon. Int J Infect Dis. 2016;52:29-36.

27. Montealegre MC, Maya JJ, Correa A, Espinal P, Mojica MF, Ruiz SJ, et al. First identification of OXA-72 carbapenemase from Acinetobacter pittii in Colombia. Antimicrob Agents Chemother. Am Soc Microbiol (ASM). 2012; 56:3996-8. 
28. Al Atrouni A, Kempf M, Eveillard M, Rafei R, Hamze M, Joly-Guillou M-L. First report of Oxa-72-producing Acinetobacter calcoaceticus in Lebanon. New Microbes New Infect. 2016;9:11-2.

29. Al Atrouni A, Joly-Guillou M-L, Hamze M, Kempf M. Emergence of NDM-1 and OXA-72 producing Acinetobacter pittii clinical isolates in Lebanon. New Microbes New Infect. 2016;12:43-4.

30. Rafei R, Dabboussi F, Hamze M, Eveillard M, Lemarié C, Gaultier M-P, et al. Molecular analysis of Acinetobacter baumannii strains isolated in Lebanon using four different typing methods. PLoS One. 2014;9:e115969 Hakami RM, editor.

31. Rafei $R$, Pailhoriès $H$, Hamze $M$, Eveillard M, Mallat $H$, Dabboussi $F$, et al. Molecular epidemiology of Acinetobacter baumannii in different hospitals in Tripoli, Lebanon using bla(OXA-51-like) sequence based typing. BMC Microbiol. 2015:15:103

32. Alkasaby NM, El Sayed Zaki M. Molecular study of Acinetobacter baumannil isolates for Metallo- $\beta$-lactamases and extended-spectrum- $\beta$-lactamases genes in intensive care unit, Mansoura University Hospital, Egypt. Int J Microbiol. 2017;2017:3925868.

33. Aly MM, Abu Alsoud NM, Elrobh MS, Al Johani SM, Balkhy HH. High prevalence of the PER-1 gene among carbapenem-resistant Acinetobacter baumannii in Riyadh, Saudi Arabia. Eur J Clin Microbiol Infect Dis. 2016;35:1759-66.

34. Beriş FŞ, Budak EE, Gülek D, Uzun A, Çizmeci Z, Mengeloğlu FZ, et al. Investigation of the frequency and distribution of beta-lactamase genes in the clinical isolates of Acinetobacter baumannii collected from different regions of Turkey: a multicenter study. Mikrobiyol Bul. 2016;50: 511-21.

35. Levy-Blitchtein S, Roca I, Plasencia-Rebata S, Vicente-Taboada W Velásquez-Pomar J, Muñoz L, et al. Emergence and spread of carbapenem-resistant Acinetobacter baumannii international clones II and III in Lima, Peru. Emerg Microbes Infect. 2018;7:119 Nature Publishing Group.

36. Mendes RE, Bell JM, Turnidge JD, Castanheira M, Jones RN. Emergence and widespread dissemination of OXA-23, -24/40 and -58 carbapenemases among Acinetobacter spp. in Asia-Pacific nations: report from the SENTRY surveillance program. J Antimicrob Chemother. 2009:63:55-9.

37. Ganjo AR, Maghdid DM, Mansoor IY, Kok DJ, Severin JA, Verbrugh HA, et al. OXA-carbapenemases present in clinical Acinetobacter baumanniicalcoaceticus complex isolates from patients in Kurdistan region, Iraq. Microb Drug Resist. 2016;22:627-37.

38. Pournaras S, Dafopoulou K, Del Franco M, Zarkotou O, Dimitroulia E, Protonotariou $\mathrm{E}_{\text {, et }}$ al. Predominance of international clone 2 OXA-23producing-Acinetobacter baumannii clinical isolates in Greece, 2015: results of a nationwide study. Int J Antimicrob Agents. 2017;49:749-53.

39. Guo L, Bao C, Liu J, Hao C, Cao J, Ye L, et al. Molecular Epidemiology of Bloodstream Infection-causing Acinetobacter baumannii from Five Tertiary Hospitals in Beijing, China. Int J Clin Med Microbiol. 2017:2:127.

40. Seng P, Rolain J-M, Fournier PE, La Scola B, Drancourt M, Raoult D. MALDITOF-mass spectrometry applications in clinical microbiology. Future Microbiol. 2010;5:1733-54.

41. Kruger T, Szabo D, Keddy KH, Deeley K, Marsh JW, Hujer AM, et al. Infections with nontyphoidal Salmonella species producing TEM-63 or a novel TEM enzyme, TEM-131, in South Africa. Antimicrob Agents Chemother. 2004:48:4263-70.

42. Roschanski N, Fischer J, Guerra B, Roesler U. Development of a multiplex real-time PCR for the rapid detection of the predominant beta-lactamase genes CTX-M, SHV, TEM and CIT-type AmpCs in Enterobacteriaceae. PLoS One. 2014;9:e100956 Bereswill S, editor. Public Library of Science.

43. Yagi T, Kurokawa H, Shibata N, Shibayama K, Arakawa Y. A preliminary survey of extended-spectrum $\hat{\imath}^{2}$-lactamases (ESBLs) in clinical isolates of Klebsiella pneumoniae and Escherichia coli in Japan. FEMS Microbiol Lett. 2000;184:53-6 Oxford University Press.

44. Rebelo AR, Bortolaia V, Kjeldgaard JS, Pedersen SK, Leekitcharoenphon P, Hansen IM, et al. Multiplex PCR for detection of plasmid-mediated colistin resistance determinants, mcr-1, mcr-2, mcr-3, mcr-4 and mcr-5 for surveillance purposes. Eurosurveillance. 2018;23. https://doi.org/10.2807/ 1560-7917.ES.2018.23.6.17-00672

45. Gupta SK, Padmanabhan BR, Diene SM, Lopez-Rojas R, Kempf M, Landraud $L$, et al. ARG-ANNOT, a new bioinformatic tool to discover antibiotic resistance genes in bacterial genomes. Antimicrob Agents Chemother 2014:58:212-20

46. Dahdouh E, Shoucair SH, Salem SE, Daoud Z. Mutant prevention concentrations of imipenem and meropenem against Pseudomonas aeruginosa and Acinetobacter baumannii. Sci World J. 2014;2014:1-7.
47. Rafei R, Hamze M, Pailhoriès $H$, Eveillard M, Marsollier L, Joly-Guillou M-L, et al. Extrahuman epidemiology of Acinetobacter baumannii in Lebanon. Appl Environ Microbiol. 2015;81:2359-67 Macfarlane GT, editor.

48. Pournaras S, Gogou V, Giannouli M, Dimitroulia E, Dafopoulou K, Tsakris A, et al. Single-locus-sequence-based typing of blaOXA-51-like genes for rapid assignment of Acinetobacter baumannii clinical isolates to international clonal lineages. J Clin Microbiol. 2014;52:1653-7.

49. Dahdouh E, Gómez-Gil R, Sanz S, González-Zorn B, Daoud Z, Mingorance J, et al. A novel mutation in pmrB mediates colistin resistance during therapy of Acinetobacter baumannii. Int J Antimicrob Agents. 2017:49:727-33.

50. Hammoudi D, Moubareck CA, Kanso A, Nordmann P, Sarkis DK. Surveillance of carbapenem non-susceptible gram negative strains and characterization of carbapenemases of classes A, B and D in a Lebanese hospital. J Med Liban. 2015;63:66-73.

51. Al Bayssari C, Dabboussi F, Hamze M, Rolain J-M. Emergence of carbapenemaseproducing Pseudomonas aeruginosa and Acinetobacter baumannii in livestock animals in Lebanon. J Antimicrob Chemother. 2015;70:950-1.
Ready to submit your research? Choose BMC and benefit from:

- fast, convenient online submission

- thorough peer review by experienced researchers in your field

- rapid publication on acceptance

- support for research data, including large and complex data types

- gold Open Access which fosters wider collaboration and increased citations

- maximum visibility for your research: over $100 \mathrm{M}$ website views per year

At $\mathrm{BMC}$, research is always in progress.

Learn more biomedcentral.com/submissions 